\title{
Metabolism of Parathyroid Hormone
}

\author{
DEGRADATION OF 125I-LABELLED HORMONE BY A KIDNEY ENZYME
}

\author{
By T. J. MARTIN, R. A. MELICK AND M. DE LUISE \\ University of Melbourne Department of Medicine, Royal Melbourne Hospital Post Office, \\ Vic. 3050, Australia
}

(Received 11 October 1968)

\begin{abstract}
A study was made of the enzymic degradation of 125 I-labelled parathyroid hormone by rat kidney microsomes. Incubation with microsomes resulted in rapid destruction of the labelled hormone. The microsomal factor was not separable by dialysis, and the reaction was favoured by $\mathrm{pH}$ values in the physiological range. Velocity of the reaction varied directly as the substrate concentration, and additional crude parathyroid hormone (trichloroacetic acid-precipitated, $3.68 \mathrm{mg}$./ ml.) inhibited destruction of labelled hormone. There was much less inhibition with added trichloroacetic acid-precipitated calcitonin $(3.92 \mathrm{mg} . / \mathrm{ml}$.$) and virtually none$ with added pig insulin $(3.80 \mathrm{mg} . / \mathrm{ml}$.). Gel filtration of control medium on P6 (Bio-Gel) yielded one radioactive peak at the void volume. After incubation with microsomes three further peaks were obtained on gel filtration. Only the voidvolume peak contained intact ${ }^{125}$ I-labelled parathyroid hormone, indicating that the microsomal enzyme degraded labelled hormone to a number of smaller fragments.
\end{abstract}

Incubation of parathyroid extract with rat kidney slices results in complete loss of detectable biological activity of the hormone, whereas other tissues have relatively little effect on the extract (Orimo, Fujita, Morii \& Nakao, 1965). Vajda, Martin \& Melick (1969) showed that homogenates of rat kidney rapidly destroyed bovine ${ }^{131}$ I-labelled parathyroid hormone, and that activity was maximal in the microsomal fraction of the kidney and was abolished by prior heating at $60^{\circ}$ for $30 \mathrm{~min}$.

The present paper describes further experiments designed to study the nature of the kidney factor and its mode of action on labelled parathyroid hormone.

\section{EXPERIMENTAL}

Chemicals. AnalaR-grade chemicals were used in all procedures. Crystalline bovine serum albumin was obtained from the Commonwealth Serum Laboratories, Parkville, Vic., Australia. [125I]Iodide was obtained from The Radiochemical Centre, Amersham, Bucks.

Hormones. Purified bovine PTH* was kindly supplied by Dr J. T. Potts, jun., and Dr G. D. Aurbach, National Institutes of Health, Bethesda, Maryland, U.S.A. It was prepared by the method of Aurbach \& Potts (1964). The pig insulin used was Lilly batch no. 81894, and crude calcitonin, potency 550 M.R.C. milli-units/mg., was prepared by phenolic extraction and precipitation with trichloroacetic acid (Martin \& Melick, 1967). Trichloroacetic acidprecipitated PTH (potency 200 units/mg.) was prepared in this Laboratory by the method of Aurbach (1959).

* Abbreviation : PTH, parathyroid hormone.
Animals. Wistar albino rats of either sex were used, and were starved overnight before experiments.

Tissue homogenization and fractionation. Rats were stunned and decapitated, the kidneys quickly removed and homogenized manually in an all-glass homogenizer with $0 \cdot 25 \mathrm{M}$-sucrose at $4^{\circ}$. After spinning at $700 \mathrm{~g}$ for $10 \mathrm{~min}$. in the small rotor of a Sorvall model $\mathrm{RC2}$ centrifuge, the supernatant fraction was centrifuged at $5000 \mathrm{~g}$ for $15 \mathrm{~min}$. The supernatant from the mitochondrial fraction was then centrifuged for $1 \mathrm{hr}$. in a Beckman model $\mathrm{L}$ ultracentrifuge at $54000 \mathrm{~g}$ in the 30 rotor. After decantation the sedimented microsomes were suspended in $10 \mathrm{ml}$. of $0.25 \mathrm{M}$-sucrose and centrifuged for $30 \mathrm{~min}$. in the 50 rotor at $148000 \mathrm{~g}$. The remaining button constituted the microsomal fraction. Electron microscopy (by courtesy of Dr K. D. Muirden) of the mitochondrial and microsomal fractions showed that the tissue-fractionation procedure was effective. The microsomal preparation was suspended in $0.25 \mathrm{M}$-sucrose and frozen in divided samples. Samples were stored at $-20^{\circ}$ and were found to retain activity for several weeks despite frequent thawing and refreezing. The protein concentration of preparations was measured by the method of Lowry, Rosebrough, Farr \& Randall (1951).

125I-labelling of hormones. Labelling of parathyroid hormone and insulin with 125I was carried out by the procedure of Hunter \& Greenwood (1962), and the 125Ilabelled peptides were purified by adsorption to Quso G 32 (Philadelphia Quartz Co.) and by elution with 20\% (v/v) acetone in $1 \%(v / v)$ acetic acid (Yalow \& Berson, 1966).

Chromatoelectrophoresis. The technique of chromatoelectrophoresis (Yalow \& Berson, 1960) was used to check the labelled hormone preparations. With this method 125I-labelled PTH remains at the origin, whereas peptide breakdown products migrate towards the anode with the plasma proteins, and free iodide migrates still further ahead 
of this fraction. Strips were scanned in a Packard radiochromatogram scanner. The same chromatoelectrophoretic technique was used to measure intact 125I-labelled PTH after incubation. Samples $(100 \mu l$.) from flasks were applied to paper (Whatman no. $3 \mathrm{MC}$ ) at $4^{\circ}$. After chromatoelectrophoresis $(0 \cdot 06 \mathrm{M}$-veronal buffer, $\mathrm{pH} 8 \cdot 6 ; 700 \mathrm{v})$ for $90 \mathrm{~min}$. the strips were dried and scanned. The origin and first $\frac{1}{2}$ in. of each strip was cut and counted in a NuclearChicago well scintillation counter.

Trichloroacetic acid preparation. In many experiments 125I-labelled PTH was measured as the trichloroacetic acidprecipitable radioactivity. Samples $(200 \mu \mathrm{l}$.) were added to $1.8 \mathrm{ml}$. of $10 \%$ trichloroacetic acid, centrifuged at $3000 \mathrm{rev} . /$ $\mathrm{min}$. for $10 \mathrm{~min}$. in an MSE centrifuge and washed once with $2 \mathrm{ml}$. of $10 \%$ trichloroacetic acid. The precipitates were counted in a Nuclear-Chicago automatic well scintillation counter. A comparison of the chromatoelectrophoretic method with the trichloroacetic acid-precipitation method of measuring intact ${ }^{125}$ I-labelled PTH revealed that there was very close agreement between the results achieved with the two procedures (Vajda et al. 1969). For this reason trichloroacetic acid precipitation alone was used in the later experiments in this series. Where both methods were used, this is indicated in the legends to Figures and Tables.

Incubation. Experiments were carried out in $25 \mathrm{ml}$. conical flasks in a shaker bath at $37^{\circ}$. Incubation mixtures consisted of $4 \mathrm{ml}$. of $0 \cdot 1 \mathrm{M}$-phosphate buffer $\left(\mathrm{KH}_{2} \mathrm{PO}_{4}, 13 \cdot 6 \mathrm{~g}\right.$. 1., $\mathrm{K}_{2} \mathrm{HPO}_{4}, 17 \cdot 4 \mathrm{~g}$./l.) $\mathrm{pH} 7 \cdot 3,1 \mathrm{ml}$. of microsomal preparation, $1 \mathrm{ml}$. of normal human serum or $1 \mathrm{ml}$. of $10 \%$ bovine serum albumin, and $100 \mu \mathrm{l}$. of $125 \mathrm{I}$-labelled PTH, about $1.5 \times 10^{6} \mathrm{counts} / \mathrm{min}$., of specific radioactivity as indicated in each experiment. Control flasks contained $1 \mathrm{ml}$. of $0.25 \mathrm{M}$ sucrose in place of the microsomal protein. The serum or bovine serum albumin was added to prevent the 125I-labelled PTH adhering to glass, which it does avidly at this $\mathrm{pH}$. Zero time was taken as that at which labelled hormone was added to the incubation medium. Small equal samples were taken from each flask at zero time and at other times as specified in different experiments. When 125I-labelled PTH was to be measured as radioactivity remaining at the origin after chromatoelectrophoresis, samples were taken from the flasks in Pasteur pipettes, and frozen immediately in small glass tubes placed in liquid $\mathrm{N}_{2}$. These were thawed in the cold-room immediately before chromatoelectrophoresis. When trichloroacetic acid-precipitable radioactivity was to be measured, $200 \mu$ l. samples were pipetted from the flasks directly into $1.8 \mathrm{ml}$. of $10 \%$ trichloroacetic acid.

Gel filtration. Gel filtration was carried out on polyacrylamide, $\mathbf{P 6}$ (Bio-Gel), in $0 \cdot 1 \mathrm{~N}$-acetic acid. Column size was $1 \mathrm{~cm} . \times 30 \mathrm{~cm}$., flow rate $2 \mathrm{ml} . / \mathrm{hr}$.; fractions were collected in tubes in a refrigerated fraction-collector (Paton Industries, Beaumont, S. Austral., Australia). Effluent protein was measured as $E$ at $280 \mathrm{~m} \mu$ in a Unicam SP.500 spectrophotometer. Radioactivity of column fractions was measured by counting $100 \mu \mathrm{l}$. samples in a Nuclear-Chicago automatic well scintillation counter.

\section{RESULTS}

The rate of destruction of ${ }^{125}$ I-labelled PTH was rapid (Fig. 1), almost $50 \%$ of the labelled hormone being destroyed in $10 \mathrm{~min}$. Increasing the substrate concentration by adding increasing amounts of

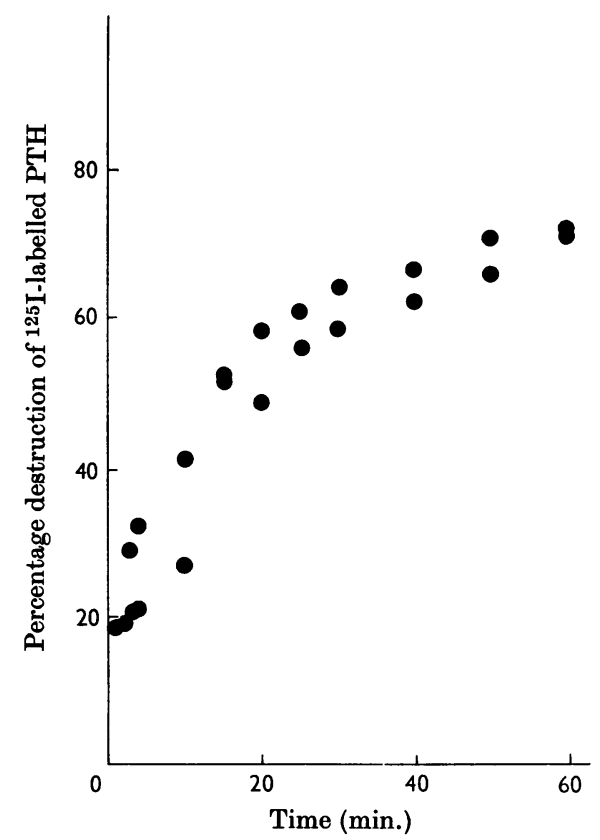

Fig. 1. Percentage destruction of 125I-labelled PTH. In each of two flasks 125 -labelled PTH $\left(1.5 \times 10^{6}\right.$ counts $/$ min., specific radioactivity $180 \mathrm{mc} / \mathrm{mg}$.) was incubated with $1 \mathrm{ml}$. of human serum, $4 \mathrm{ml}$. of $0 \cdot 1 \mathrm{M}$-phosphate buffer and $1 \mathrm{ml}$. of microsomes $(700 \mu \mathrm{g}$. of protein) in $0.25 \mathrm{M}$-sucrose. Small equal samples were taken from each flask at short timeintervals, and frozen in liquid $\mathrm{N}_{2}$. After thawing at $4^{\circ}$, $100 \mu$ l. samples were subjected to chromatoelectrophoresis. Intact 125I-labelled PTH was measured as the radioactivity remaining at the origin.

labelled hormone led to a progressive increase in reaction velocity (Fig. 2). The maximum velocity of the reaction was not reached in these experiments.

The result of an examination of the specificity of the microsomal degradation of 125I-labelled PTH is given in Fig. 3. A large excess of trichloroacetic acid-precipitated PTH almost completely inhibited the destruction of labelled PTH. A similar concentration of trichloroacetic acid-precipitated calcitonin caused considerably less inhibition and crystalline pig insulin had very little effect on the rate of the reaction.

A comparison was made of the effects of microsomal and mitochondrial fractions from liver and kidney on pig 125I-labelled insulin and PTH. The results in Table 1 show that after incubation for $15 \mathrm{~min}$. there was virtually no effect of either kidney fraction on the 125I-labelled insulin, whereas considerable destruction of 125 I-labelled PTH was caused by the kidney microsomal fraction and somewhat less by the mitochondrial fraction. The liver fractions had no effect on ${ }^{125}$ I-labelled PTH. 


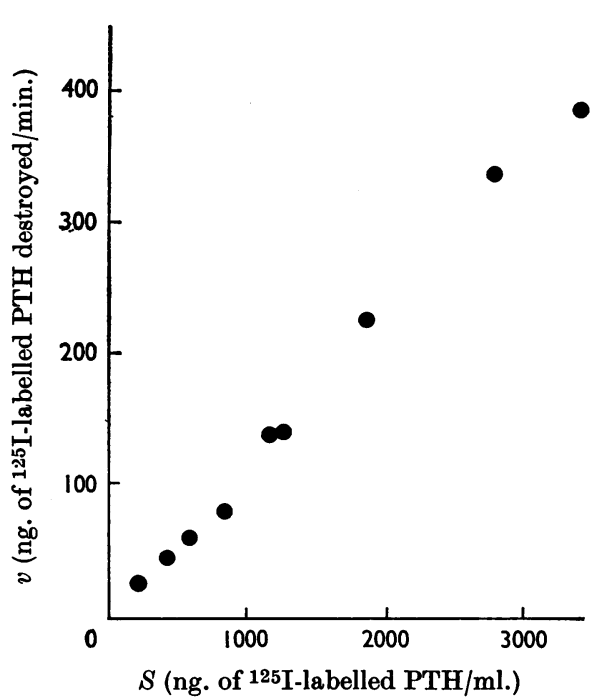

Fig. 2. Effect of increasing concentration $(S)$ of $125 \mathrm{I}$ labelled PTH on the rate of destruction $(v)$ of $125 I$-labelled PTH. Incubation flasks contained $0.5 \mathrm{ml}$. of $10 \%$ bovine serum albumin, $2 \mathrm{ml}$. of $0.1 \mathrm{M}$-phosphate buffer and $0.25 \mathrm{ml}$. of microsomes $(250 \mu \mathrm{g}$. of protein) in $0.25 \mathrm{M}$-sucrose in addition to the labelled hormone, of specific radioactivity $36 \mathrm{mc} / \mathrm{mg}$. Samples $(200 \mu \mathrm{l}$.) were taken from each flask at 0 and $15 \mathrm{~min}$., and intact $125 \mathrm{I}$-labelled PTH was measured by precipitation with $10 \%$ trichloroacetic acid. As the total 125I-labelled PTH content of each flask was known, the rate of destruction/min. was calculated from the observed percentage destruction at $15 \mathrm{~min}$.

Earlier experiments (Vajda et al. 1969) have shown the lack of effect of the rat kidney microsomal fraction on 125I-labelled human growth hormone and the very slight effect on 131I-labelled insulin.

The process was slowed considerably by acid conditions, and an optimum $\mathrm{pH}$ in the physiological range was apparent (Table 2). After dialysis at $4^{\circ}$ for $48 \mathrm{hr}$. against four changes of $0.25 \mathrm{M}$-sucrose the microsomal fraction retained its capacity to destroy 125I-labelled PTH (Table 3).

Gel filtration on P6 (Bio-Gel) in $0 \cdot 1 \mathrm{~N}$-acetic acid was used to study the products of kidney microsomal degradation of 125I-labelled PTH. Fig. 4 shows the elution profile after chromatography of $0.4 \mathrm{ml}$. of control medium consisting of ${ }^{125}$ I-labelled PTH in buffer, bovine serum albumin and sucrose, incubated for $45 \mathrm{~min}$. There was one radioactive peak indicating the emergence of labelled PTH (mol.wt. 8600) and albumin at the void volume of the column. The same preparation after incubation for $45 \mathrm{~min}$. in the microsomal preparation yielded four peaks (Fig. 5). With longer incubation there was a decline in peak $I$ (125I-labelled PTH) and an increase in the lower-molecular-weight fractions. In particular,

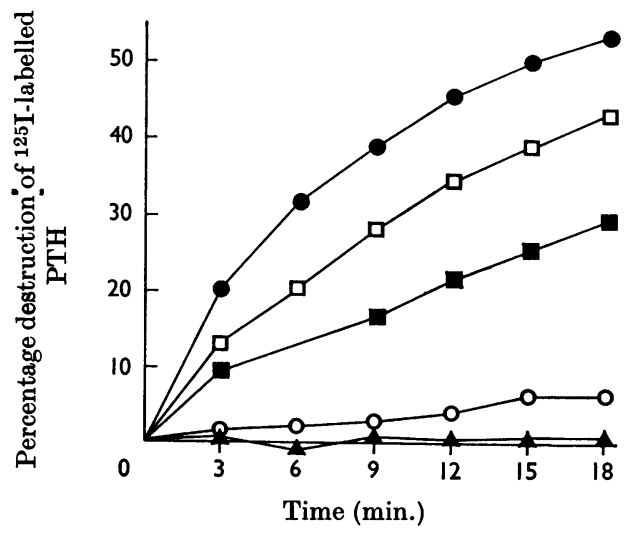

Fig. 3. Effects of added pig insulin, trichloroacetic acidprecipitated calcitonin and trichloroacetic acid-precipitated PTH on the destruction of ${ }^{125}$ I-labelled PTH by rat kidney microsomes. All flasks contained $0.5 \mathrm{ml}$. of $10 \%$ bovine serum albumin, $1.7 \mathrm{ml}$. of $0.1 \mathrm{~m}$-phosphate buffer and $1.5 \times 10^{6}$ counts $/ \mathrm{min}$. of $125 \mathrm{I}$-labelled PTH. Other contents are represented as follows: $\bullet, 250 \mu \mathrm{g}$. of microsomal protein in $0.25 \mathrm{ml}$. of $0.25 \mathrm{M}$-sucrose, and $0.3 \mathrm{ml}$. of $0.1 \mathrm{~N}$-acetic acid; $\square, 250 \mu \mathrm{g}$. of microsomal protein in $0.25 \mathrm{ml}$. of $0.25 \mathrm{M}$ sucrose, and $11.1 \mathrm{mg}$. of pig insulin in $0.3 \mathrm{ml}$. of $0.1 \mathrm{~N}$-acetic acid; $\square, 250 \mu \mathrm{g}$. of microsomal protein in $0.25 \mathrm{ml}$. of $0.25 \mathrm{M}$ sucrose, and $10.9 \mathrm{mg}$. of trichloroacetic acid-precipitated calcitonin in $0.3 \mathrm{ml}$. of $0 \cdot 1 \mathrm{~N}$-acetic acid; $\bigcirc, 250 \mu \mathrm{g}$. of microsomal protein in $0.25 \mathrm{ml}$. of $0.25 \mathrm{M}$-sucrose, and $11.0 \mathrm{mg}$. of trichloroacetic acid-precipitated PTH in $0.3 \mathrm{ml}$. of $0.1 \mathrm{~N}-$ acetic acid; $\Delta, 0.25 \mathrm{ml}$. of $0.25 \mathrm{M}$-sucrose and $0.3 \mathrm{ml}$. of $0 \cdot 1 \mathrm{~N}$-acetic acid. Intact $125 \mathrm{I}$-labelled PTH was measured by precipitation with $10 \%$ trichloroacetic acid.

Table 1. Effects of kidney and liver mitochondria and microsomes on 125I-labelled parathyroid hormone and 125I-labelled insulin

Incubation flasks contained $1 \mathrm{ml}$. of human serum. Intact 125I-labelled PTH and 125I-labelled insulin were measured by precipitation with trichloroacetic acid. Specific radioactivities: ${ }^{125} \mathrm{I}$-labelled PTH, $65 \mathrm{mc} / \mathrm{mg}$.; ${ }^{125} \mathrm{I}$-labelled insulin, $180 \mathrm{mc} / \mathrm{mg}$.

Destruction of hormone (\% in $15 \mathrm{~min}$.

\section{Incubation system}

Control

Kidney microsomes

Kidney mitochondria

Liver microsomes

Liver mitochondria

$\begin{array}{cc}\text { 125I-labelled } & \begin{array}{c}\text { 125I-labelled } \\ \text { PTH }\end{array} \\ 0.6 & -1 \cdot 2 \\ 42 \cdot 4 & 4 \cdot 4 \\ 27 \cdot 0 & 4 \cdot 0 \\ 0 \cdot 1 & 0 \cdot 8 \\ 6.6 & 20 \cdot 7\end{array}$

peak IV increased with prolonged incubation. The results of trichloroacetic acid precipitation of equal samples from the different peaks are shown in Table 4. When the pooled freeze-dried column 
Table 2. Effect of $\mathrm{pH}$ of incubation on the destruction of 125I-labelled parathyroid hormone by rat kidney microsomal preparation

Medium contained $10 \%$ bovine serum albumin. Intact 125I-labelled PTH was measured by precipitation with trichloroacetic acid. Specific radioactivity of ${ }^{125 I}$-labelled PTH was $220 \mathrm{mc} / \mathrm{mg}$.

\begin{tabular}{|c|c|c|c|}
\hline \multirow[b]{2}{*}{ Buffer } & \multirow[b]{2}{*}{$\mathrm{pH}$} & \multicolumn{2}{|c|}{$\begin{array}{c}\text { Destruction of } \\
\text { 125I-labelled PTH } \\
\text { (\% in } 15 \mathrm{~min} .)\end{array}$} \\
\hline & & Control & Microsomes \\
\hline n's citrate & $2 \cdot 4$ & $1 \cdot 7$ & 1.5 \\
\hline n's citrate & $3 \cdot 2$ & $-2 \cdot 5$ & $5 \cdot 6$ \\
\hline a's citrate & $4 \cdot 2$ & -0.3 & $12 \cdot 1$ \\
\hline n's phosphate & $5 \cdot 3$ & 1.8 & $47 \cdot 3$ \\
\hline n's phosphate & $6 \cdot 3$ & $2 \cdot 6$ & $60 \cdot 1$ \\
\hline n's phosphate & $7 \cdot 3$ & $2 \cdot 0$ & $59 \cdot 7$ \\
\hline n's phosphate & $8 \cdot 2$ & -0.9 & $50 \cdot 8$ \\
\hline n's glycine & $9 \cdot 3$ & 0.2 & $37 \cdot 1$ \\
\hline
\end{tabular}

\section{Table 3. Effect of dialysis on microsomal activity}

Microsomal suspension was dialysed in Visking tubing (25/32) against four changes of $0 \cdot 25 \mathrm{M}$-sucrose at $4^{\circ}$ for $48 \mathrm{hr}$. Flasks 2 and 3 contained equal quantities of microsomal protein. Medium contained $10 \%$ bovine serum albumin; intact 125I-labelled PTH was measured by precipitation with trichloroacetic acid. Specific radioactivity of 125I-labelled PTH was $240 \mathrm{mc} / \mathrm{mg}$.

\begin{tabular}{llc}
\multicolumn{1}{c}{ Flask } & $\begin{array}{c}\text { Destruction of 125I-labelled } \\
\text { PTH (\% in 40 min.) }\end{array}$ \\
1. Control & $-1 \cdot 5$ \\
2. Non-dialysed microsomes & $\mathbf{7 7 \cdot 4}$ \\
3. Dialysed microsomes & $\mathbf{7 7 \cdot 1}$
\end{tabular}

fractions were examined by chromatoelectrophoresis, only peak I was found to contain material that remained at the origin. With the control flask, all radioactivity remained at the origin. Incubation with the microsomal preparation gave a front peak of radioactivity, most of which remained at the origin. However, there was a small mobile fraction in this peak on chromatoelectrophoresis, and not all the radioactivity in this peak was precipitated by trichloroacetic acid (Table 2). The remaining three peaks contained no material remaining at the origin, and it should be noted that even in the fraction of lowest molecular weight, peak IV, there was no evidence for the presence of free iodide on chromatoelectrophoresis.

\section{DISCUSSION}

The results of these experiments show that the microsomal fraction of rat kidney contains a non-diffusible factor that rapidly degrades 125I-

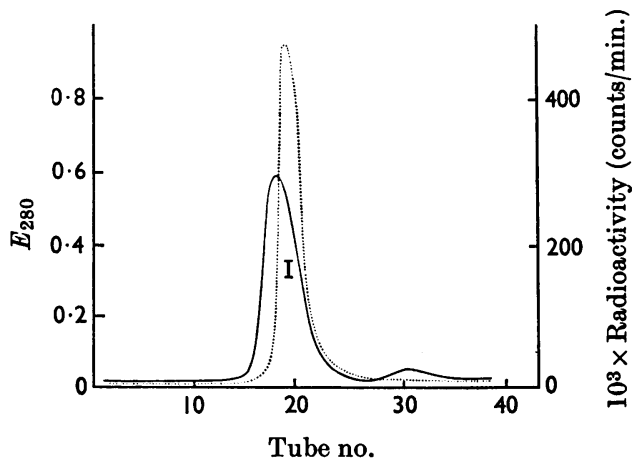

Fig. 4. Gel-filtration chromatography of $1 \mathrm{ml}$. of control medium on a column $(30 \mathrm{~cm} . \times 1 \mathrm{~cm}$.) of polyacrylamide $\mathbf{P 6}$ (Bio-Gel) in $0.1 \mathrm{~N}$-acetic acid. Fractions (30 drops) were collected at a flow rate of $8 \mathrm{ml}$./hr., examined spectrophotometrically at $280 \mathrm{~m} \mu$, and $100 \mu l$. samples were counted in a Nuclear-Chicago automatic well scintillation counter. 125I-labelled PTH ( $10^{7}$ counts/min., specific radioactivity $210 \mathrm{mc} / \mathrm{mg}$.) had been incubated for $45 \mathrm{~min}$. with $0.5 \mathrm{ml}$. of $10 \%$ bovine serum albumin, $2 \mathrm{ml}$. of $0 \cdot 1 \mathrm{M}$-phosphate buffer and $0.25 \mathrm{ml}$. of $0.25 \mathrm{M}$-sucrose.,$- E_{280} ; \ldots$, counts $/ \mathrm{min}$.

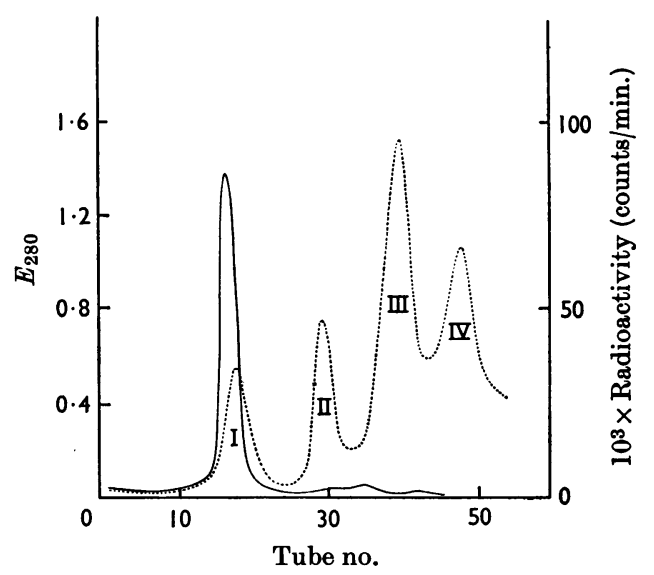

Fig. 5. Gel-filtration chromatography of $1 \mathrm{ml}$. of medium after incubation of ${ }^{125}$ I-labelled PTH with microsomes. Gelfiltration conditions were as described in Fig. 4. 125Ilabelled PTH (107 counts/min., specific radioactivity 180 $\mathrm{mc} / \mathrm{mg}$.) had been incubated for $45 \mathrm{~min}$. with $0.5 \mathrm{ml}$. of $10 \%$ bovine serum albumin, $2 \mathrm{ml}$. of $0.1 \mathrm{M}$-phosphate buffer and $0.25 \mathrm{ml}$. of microsomes $(280 \mu \mathrm{g}$. of protein) in $0.25 \mathrm{M}$ sucrose. -, $E_{280} ; \ldots$, counts/min.

labelled PTH to a number of peptide fragments. The reaction is favoured by $\mathrm{pH}$ in the physiological range, and the reaction velocity is increased by increasing the substrate concentration. These findings provide further evidence that the micro- 
Table 4. Trichloroacetic acid solubility of $P 6$ (Bio-Gel) column fractions

The trichloroacetic acid solubility of the 125I-labelled peptides was studied by examining a number of tubes from individual peaks after gel filtration (see Figs. 4 and 5). Samples $(200 \mu \mathrm{l}$.) from fraction-collector tubes were added to $200 \mu \mathrm{l}$. of human serum, precipitated with $3.6 \mathrm{ml}$. of $10 \%$ trichloroacetic acid and washed once. Radioactivity of the precipitates was expressed as a percentage of the total counts in the $200 \mu \mathrm{l}$. samples. Means \pm S.E.M. of four tubes from each column peak are given.

Radioactivity precipitated by trichloroacetic acid

Column Peak (\% of total)

Control flask $\quad$ I $\quad 95 \cdot 2 \pm 0 \cdot 34$

(Fig. 4)

Microsome flask

(Fig. 5)

$\begin{array}{lr}\text { I } & 76 \cdot 1 \pm 0.66 \\ \text { II } & 0 \cdot 8 \pm 0.20 \\ \text { III } & 1 \cdot 0 \pm 0.38 \\ \text { IV } & 0.5 \pm 0 \cdot 16\end{array}$

somal factor is a proteolytic enzyme. This was suggested after the demonstration that the process was dependent on temperature and on the quantity of microsomal protein, and that the activity was destroyed by prior heating at $60^{\circ}$ for $30 \mathrm{~min}$. (Vajda et al. 1969).

There was competitive inhibition of 125 I-labelled PTH degradation when an excess of trichloroacetic acid-precipitated PTH was included in the incubation medium, although we have no evidence of the relative susceptibility of the native and labelled hormones to the enzyme. Narahara \& Williams (1957) found that the addition of labelled glucagon was slightly more effective than unlabelled glucagon in suppressing degradation of the 125I-labelled hormone, suggesting that the manipulations involved in iodination caused slight changes in the glucagon that rendered it a better substrate for proteolysis. In our experiments some competitive inhibition occurred with an excess of trichloroacetic acid-precipitated calcitonin also, and very little was seen with insulin. Competition between insulin and glucagon for a liver enzyme has been claimed (Tomizawa \& Williams, 1955), and between insulin and oxytocin for a renal cortical enzyme (Camu \& Conard, 1966). The possibility of competition between PTH and calcitonin for the kidney microsomal enzyme awaits study with purer hormone preparations. Although there is evidence that the kidney causes insulin degradation (Mirsky \& Broh-Kahn, 1949), assessed at $75 \%$ of the liver activity (Williams, Hay \& Tjaden, 1959), nevertheless kidney microsomes had little effect on 125I-labelled insulin. Therefore insulin must be degraded by a kidney mechanism separate from the one we have studied for PTH.
The formation of a number of 125I-labelled fractions after incubation of ${ }^{125}$ I-labelled PTH with the microsomal preparation suggests that the enzyme acts at more than one location in the parathyroid hormone molecule, since the latter contains only one tyrosine residue available for iodination (Potts, Aurbach \& Sherwood, 1966). The results of gel filtration on P6 (Bio-Gel) indicated that at least three smaller fragments of the parathyroid hormone molecule were formed. Although 125I-labelled PTH emerged at the void volume, remained at the origin on chromatoelectrophoresis and was fully precipitated by trichloroacetic acid, the radioactivity in peak $I$ after incubation of 125I-labelled PTH with microsomes was partly mobile on chromatoelectrophoresis and not fully precipitated by trichloroacetic acid. The explanation could be that a fragment of the molecule had been formed of molecular weight greater than 4600 , the exclusion limit of P6 (Bio-Gel). If this were so, however, it is likely that the fragment would be precipitable by trichloroacetic acid. A more probable explanation is that proteolytic digestion continued albeit slowly even in $0.1 \mathrm{~N}$-acetic acid, since the enzyme would also emerge at the void volume of the column. When pooled fractions of peak I were freeze-dried and reconstituted in plasma for chromatoelectrophoresis the mobile component became more prominent. Freezedrying of the column peak from a control incubation, on the other hand, did not give rise to any change in the chromatoelectrophoretic pattern.

Studies of the metabolism of peptide hormones have revealed tissue enzymes concerned with the proteolytic breakdown of the hormone molecules (Mirsky \& Broh-Kahn, 1949). The liver insulinase (Mirsky, Perisutti \& Dixon, 1954) was found to be considerably more active than the kidney enzyme in degrading insulin (Williams et al. 1959). Vajda et al. (1969) found kidney most active in destroying 125I-labelled PTH, with much less activity in skeletal muscle, still less in liver, lung and spleen. The earliest experiments of Mirsky's group (Mirsky \& Broh-Kahn, 1949; Mirsky \& Perisutti, 1953) were done by using a biological assay for insulin. Their findings were confirmed fully when they used 131I-labelled insulin. Most of the work on tissue destruction of peptide hormones since then has been achieved with labelled hormones. The present experiments confirm the results obtained by Orimo et al. (1965), with biological assay, and indicate the presence in rat kidney of a proteolytic enzyme that degrades parathyroid hormone in vitro in amounts far in excess of the estimated secretion rate of the hormone in vivo (Melick, Aurbach \& Potts, 1965). This provides further evidence of the importance of the kidney in parathyroid hormone metabolism.

Bioch. 1969, 111 
We are grateful to Professor V. M. Trikojus for helpful advice in the preparation of the manuscript, to $\mathrm{Dr}$ J. T. Potts, jun., and Dr G. D. Aurbach for supplying pure bovine parathyroid hormone, and to $\mathrm{Dr} K$. D. Muirden for carrying out electron microscopy of the tissue fractions. This investigation was supported by a grant from the National Health and Medical Research Council of Australia.

\section{REFERENCES}

Aurbach, G. D. (1959). J. biol. Chem. 234. 3179.

Aurbach, G. D. \& Potts, J. T., jun. (1964). Endocrinology, 75, 290.

Camu, F. \& Conard, V. (1966). Arch. int. Pharmacodyn. $162,247$.

Hunter, W. M. \& Greenwood, F. C. (1962). Nature, Lond., $194,495$.

Lowry, O. H., Rosebrough, N. J., Farr, A. L. \& Randall, R. J. (1951). J. biol. Chem. 193, 265.

Martin, T. J. \& Melick, R. A. (1967). Med. J. Aust. 2, 519 (abstr.).
Melick, R. A., Aurbach, G. D. \& Potts, J. T., jun. (1965). Endocrinology, 77, 198.

Mirsky, I. A. \& Broh-Kahn, R. H. (1949). Arch. Biochem. 20, 1.

Mirsky, I. A. \& Perisutti, G. (1953). Endocrinology, 52, 698.

Mirsky, I. A., Perisutti, G. \& Dixon, F. J. (1954). Proc. Soc. exp. Biol., N.Y., 86, 228.

Narahara, H. T. \& Williams, R. H. (1957). Endocrinology, 60, 285.

Orimo, H., Fujita, T., Morii, H. \& Nakao, K. (1965). Endocrinology, 76, 255.

Potts, J. T., jun., Aurbach, G. D. \& Sherwood, L. M. (1966). Recent Progr. Hormone Res. 22, 101.

Tomizawa, H. H. \& Williams, R. H. (1955). J. biol. Chem. 217, 685.

Vajda, F. J. E., Martin, T. J. \& Melick, R. A. (1969). Endocrinology, 84 (in the Press).

Williams, R. H., Hay, J. S. \& Tjaden, M. B. (1959). Ann. N.Y. Acad. Sci. 74, 513.

Yalow, R. S. \& Berson, S. A. (1960). J. clin. Invest. 39, 1157. Yalow, R. S. \& Berson, S. A. (1966). Nature, Lond., 212, 357. 